\title{
Behavior of dissolved silica in connection with oxidation-reduction cycle in lake water
}

\author{
KIKUO KaTO \\ Water Research Laboratory, Faculty of Science, \\ Nagoya University, Chikusa, Nagoya, Japan \\ (Received December 26, 1968; in revised form March 8, 1969)
}

\begin{abstract}
Dissolved silica is removed from lake water through its co-precipitation with hydrated oxides of iron and manganese. Dissolution of hydrated oxides of iron and manganese (orange floccules) including co-precipitated silica in the bottom sediment of lake causes a simultaneous increase in the dissolved silica content with increase in the dissolved iron and manganese contents of hypolimnionic water. The behavior of dissolved silica is thus controlled by the oxidation-reduction cycle in lake water.
\end{abstract}

\section{INTRODUCTION}

Seasonal variation in vertical distribution of dissolved silica in lake water has been well known, since it was observed by YoshimuRA (1930) at Takasukanuma, a small eutrophic lake in Saitama Pref., Japan.

Factors controlling the seasonal variation in vertical distribution of dissolved silica in lake water have been studied by Yoshimura (1930, 1939), Meloche et al. (1938), Elster (1939), VinOgradov and Boichenko (1942), Lewin (1954, 1955) and HARRIS (1967). They are circulation of water, inflow of river water and underground water, assimilation of dissolved silica by organisms secreting silica, dissolution of silica from organisms, decomposition of silicate minerals by inorganic and biochemical processes and diffusion of dissolved silica in lake water.

Co-precipitation of silica with hydrated oxides of iron and manganese, and dissolution of the co-precipitated silica are proposed here as more significant factors controlling the concentration of dissolved silica. The purpose of this study is to discuss the behavior of dissolved silica, therefore, in connection with an oxidationreduction cycle in lake water.

\section{Behavior of Dissolved Silica, Iron and Manganese in Lake Water}

Fig. 1 shows the seasonal variation in vertical distribution of dissolved iron and manganese as well as dissolved silica in Lake Kizaki, a mesotrophic mountain lake in Nagano Pref., Japan. During a circulation period, e.g. on March 14, 1965, vertical distributions of water temperature, $\mathrm{pH}$, dissolved oxygen and dissolved silica are 

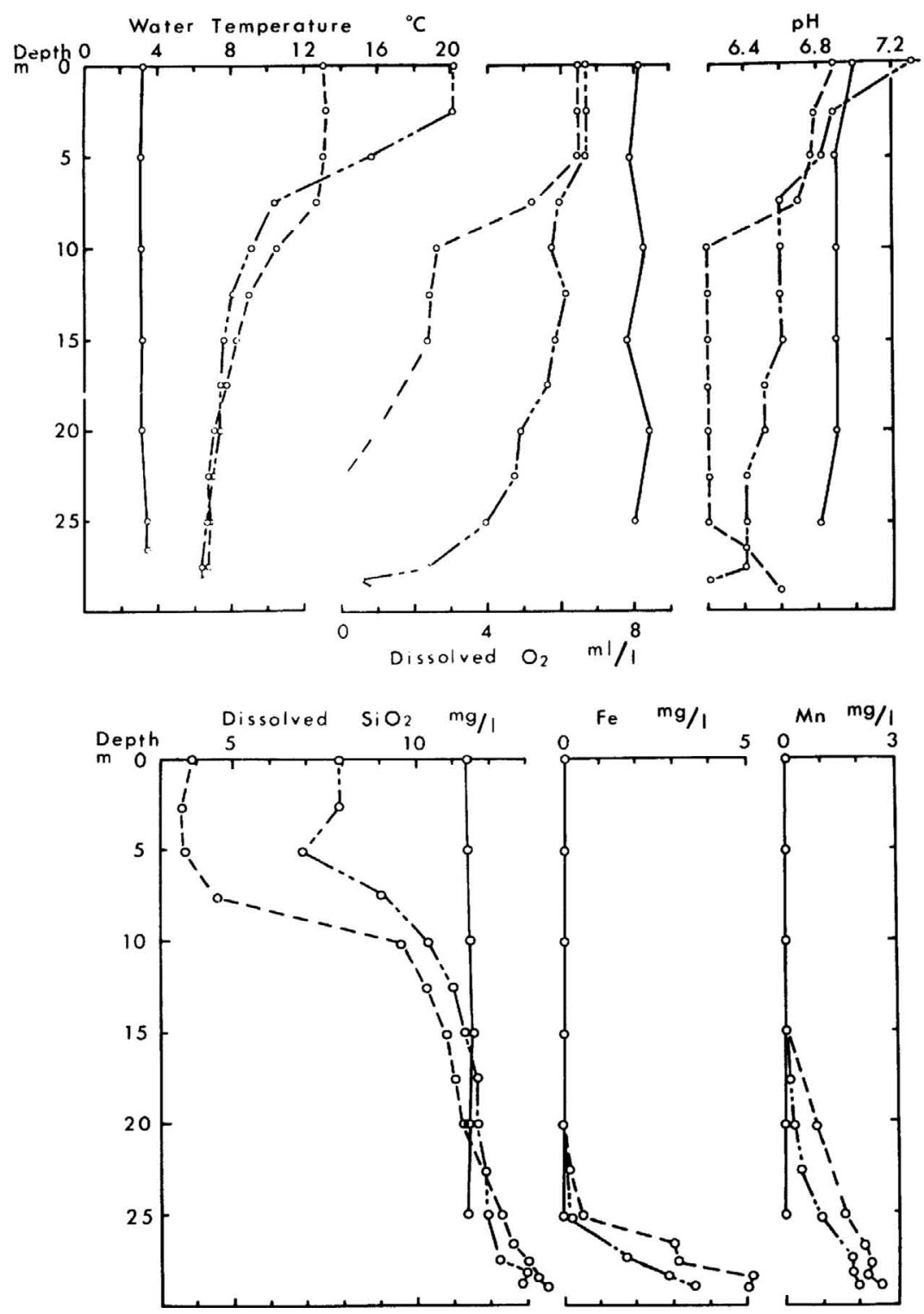

Fig.1. Seasonal variation in vertical distribution of various components of water in Lake Kizaki (water temperature, $\mathrm{pH}$ and dissolved $\mathrm{O}_{2}$ content were determined by KOYAMA and TOMINO, 1967).

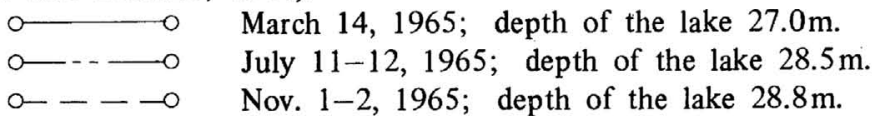


uniform and dissolved iron and manganese contents are uniformly close to zero. During a stagnation period, e.g. on July 11-12 and November 1-2, 1965, the chemical composition of hypolimnionic water changes. As the season advances, dissolved oxygen content decreases with depth and drops to zero in hypolimnionic water, whereas dissolved iron and manganese appear and increase in hypolimnionic water. Dissolved silica content decreases in epilimnionic water and increases in hypolimnionic water.

The seasonal variations in vertical distributions of dissolved iron and manganese resemble that of dissolved silica except for its decrease in epilimnionic water. This may indicate a probable cycle of dissolved silica along with iron and manganese.

Furthermore, the following fact is seen from YoshimurA's data on the continual observation of the seasonal variations in vertical distributions of dissolved silica (1930, 1939) and dissolved iron and manganese (1931) at Takasuka-numa during the years 1929-1931: The dissolved silica content of hypolimnionic water increased markedly and simultaneously with a marked increase in the dissolved iron and manganese contents at the early stage of the summer stratification, and a sudden and marked decrease in the dissolved silica content coincided with such a decrease in the dissolved iron and manganese contents at the last stage of the summer stratification.

Mortimer $(1941,1942)$ found in his experiments that the dissolved silica content of the water over mud in Lake Windermere increased to only $30 \mathrm{mg} / \ell$ under aerobic condition but under anaerobic condition increased greatly to about $100 \mathrm{mg} / \ell$, close to the solubility of amorphous silica. He also found that under anaerobic condition the dissolved silica content increased coincidentally with increase in the iron content, like the phosphate content but to a lesser degree, and decreased when oxygen was accidentally introduced to the solution.

These facts can not always be explained by the controlling factors reported by previous investigators, but rather suggest that the behavior of dissolved silica depends upon the oxidation-reduction of iron and manganese, as was previously reported on the behavior of phosphorus (EINSELE, 1936, 1938; OHLE, 1953), sulphate (KoYAMA and Sugawara, 1951), iodine (Sugawara et al., 1958) and arsenic (Kanamori, 1965). Very little, however, is known about that of silica (HARDER, 1965).

\section{EXPERIMENTAL}

Chemical analysis

Dissolved silica: Colorimetric determination with ammonium molybdate (KATO and KitanO, 1966).

Ferrous iron: Colorimetric determination with 2,2'- bipyridyl(Moss and MELlon, 1942). Total iron: Colorimetric determination after extraction with 8-hydroxyquinoline and chloroform at $\mathrm{pH} 5.0$. 
Manganese: Colorimetric determination after extraction with 8-hydroxyquinoline and chloroform at $\mathrm{pH} 10.0$.

Dissolved oxygen: Winkler's method.

Chloride: Mohr's method or colorimetric determination with mercuric thiocyanate (IWASAKI et al., 1956).

\section{Experimental procedure}

Experiments were made in polyethylene bottles at $20 \pm 1^{\circ} \mathrm{C}$. Iron and manganese solutions were prepared from iron chloride and potassium permanganate, respectively.

Silica solution was prepared: About $500 \mathrm{mg}$ of powdered silica gel or quartz was dried at about $700^{\circ} \mathrm{C}$, fused with $4.0 \mathrm{~g}$ of sodium carbonate, and dissolved in dilute hydrochloric acid, the $\mathrm{pH}$ value being adjusted to about 7.0. The silica solution was standardized gravimetrically.

1. Co-precipitation of dissolved silica with hydrated oxides of iron and manganese

a) A known amount of iron or manganese in acid solution was added to the solution containing a known amount of dissolved silica. The $\mathrm{pH}$ value was adjusted to $5.0-8.0$ by adding sodium hydroxide solution.

b) Lake water under anaerobic condition had been sampled out of contact with air. Then the lake water was kept stood in contact with air.

c) A known amount of iron or manganese in acid solution was added to the lake water. The $\mathrm{pH}$ value was adjusted to the original value of the lake water by adding sodium hydroxide solution.

In each case, dissolved silica, iron and manganese were determined before and 2 days after addition of sodium hydroxide solution.

2. Dissolution of the hydrated oxides including co-precipitated silica

a) Two hundred $\mathrm{mg}$ of $\ell$-ascorbic acid or $5 \mathrm{ml}$ of $1 \mathrm{M}$ perchloric acid was added to a $100 \mathrm{ml}$-portion of the solution containing co-precipitants, which had been prepared by the experimental porcedure 1 .

b) Five $\mathrm{ml}$ of $1 \mathrm{M}$ perchloric acid was added to a $100 \mathrm{ml}$-portion of distilled water containing orange floccules of hydrated oxides of iron and manganese sampled from the bottom sediment of Lake Kizaki.

In each case dissolved silica, iron and manganese in the solution were determined before and $1 \mathrm{hr}$ after addition of acid.

\section{RESUlTS AND Discussion}

Co-precipitation of silica with hydrated oxides of iron and manganese and dissolution of them

Fig. 2 and Table 1 show experimental results on co-precipitation of silica with hydrated oxide of iron or manganese. Hydrated oxides of iron and manganese obviously co-precipitate a considerable amount of dissolved silica. This depends on $\mathrm{pH}$ 


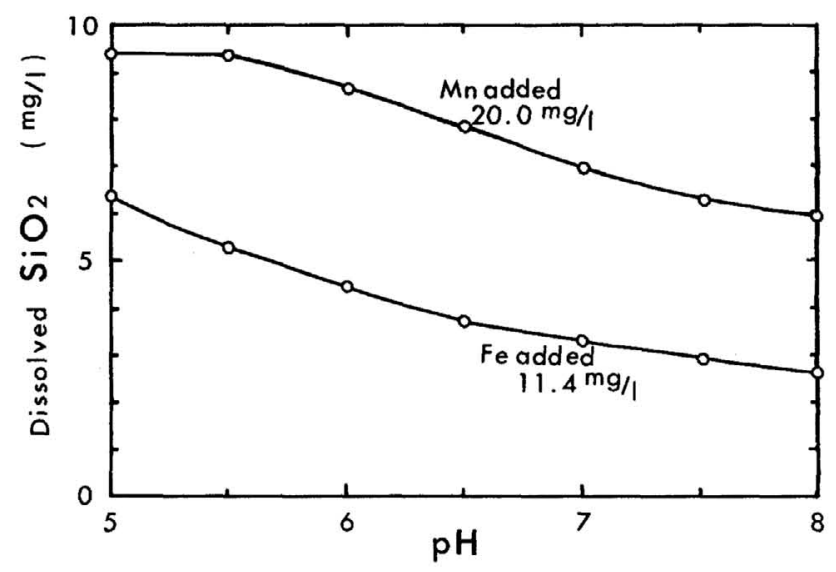

Fig.2. Change in the dissolved silica content with $\mathrm{pH}$ after co-precipitation of silica with hydrated oxide of iron or manganese. Acid solution of iron or manganese was added to a solution containing $9.3 \mathrm{mg} / \ell$ of dissolved silica.

Table 1. Co-precipitated silica at $\mathrm{pH} 7.0$ with hydrated oxide of iron or manganese formed by adding iron or manganese in acid solution to a solution containing $9.3 \mathrm{mg} / \mathrm{l}$ of dissolved silica.

\begin{tabular}{|c|c|c|c|c|}
\hline $\begin{array}{c}\text { Temperature } \\
{ }^{\circ} \mathrm{C}\end{array}$ & $\begin{array}{c}\text { Fe added } \\
\mathrm{mg} / \ell\end{array}$ & $\begin{array}{c}\text { co-precipitated } \\
\mathrm{SiO}_{2} \\
\mathrm{mg} / \mathrm{l}\end{array}$ & $\begin{array}{c}\text { Mn added } \\
\mathrm{mg} / \mathrm{l}\end{array}$ & $\begin{array}{c}\text { co-precipitated } \\
\mathrm{SiO}_{2} \\
\mathrm{mg} / \ell\end{array}$ \\
\hline 5 & 3.8 & 2.9 & 5.0 & 0.5 \\
\hline 20 & 3.8 & 2.7 & 5.0 & 0.2 \\
\hline 40 & 3.8 & 2.2 & 5.0 & 0.2 \\
\hline 5 & 11.4 & 6.3 & 10.0 & 0.8 \\
\hline 20 & 11.4 & 6.0 & 10.0 & 0.4 \\
\hline 40 & 11.4 & 5.6 & 10.0 & 0.3 \\
\hline 5 & 38.0 & 7.2 & 50.0 & 3.4 \\
\hline 20 & 38.0 & 7.1 & 50.0 & 3.2 \\
\hline 40 & 38.0 & 6.9 & 50.0 & 2.8 \\
\hline
\end{tabular}

value, temperature of the solution and the ratio of dissolved silica to added iron or manganese. The amount of silica co-precipitated with hydrated oxides increases with increase in the value of $\mathrm{pH}$ between 5.0 and 8.0 and with decrease in temperature. With increase in the amount of added iron or manganese, the amount of co-precipitated silica increases but the ratio of co-precipitated silica to iron or manganese (the efficiency of co-precipitation of silica) decreases. 
It is seen from the results that the dissolved silica is removed from solution through co-precipitation with hydrated oxides of iron and manganese. A sudden and marked decrease in the dissolved silica content of hypolimnionic water at the last stage of stratification is probably due to co-precipitation of silica with hydrated oxides which are formed by introduction of dissolved oxygen.

Next, hydrated oxides of iron and manganese including co-precipitated silica were dissolved by adding $\ell$-ascorbic acid or $1 \mathrm{M}$ perchloric acid. Under anaerobic condition or at low $\mathrm{pH}$ values of the solution, the hydrated oxides were completely dissolved and co-precipitated silica were changed to dissolved silica. This implies a simultaneous increase in the dissolved silica content with increase in the iron and manganese contents of hypolimnionic water during a stagnation period. Thus under anaerobic condition dissolved silica content of water over mud becomes much larger than that under aerobic condition.

Further in some lakes, dissolved iron and manganese are brought by inflowing water or underground water, precipitated in the epilimnion and then dissolved in the hypolimnion. There, through co-precipitation of silica with hydrated oxides of iron and manganese and dissolution of the co-precipitated silica, silica is transported from the epilimnion to the hypolimnion.

Thus, co-precipitation of dissolved silica with hydrated oxides of iron and manganese and dissolution of co-precipitated silica explain the behavior of dissolved silica in correlation to oxidation-reduction cycle in lake water. It becomes reasonable that the seasonal variation in vertical distribution pattern of dissolved silica resembles that of not only dissolved iron and manganese but also phosphorus, iodine and arsenic, the behavior of which is attributed to the oxidation-reduction of iron and manganese.

Co-precipitation of silica with hydrated oxides of iron and manganese in hypolimnionic water

Co-precipitation of silica with hydrated oxides of iron and manganese was examined in natural lake waters. Table 2 presents the results obtained using hypolimnionic water of Lake Aburagafuchi, a eutrophic brackish lake in Aichi Pref., Japan. The dissolved silica content of the water decreases by 2.4 to $4.3 \mathrm{mg} / \mathrm{l}$ after precipitation of hydrated oxides.

Thus, dissolved silica is removed from natural lake water through its co-precipitation with hydrated oxides of iron and manganese. The amount of co-precipitated silica in lake water, however, is greatly less than the present experimental result as follows: The amount of dissolved silica removed from a solution containing $18.3 \mathrm{mg} / \ell$ of dissolved silica and $16.0 \mathrm{mg} / \ell$ of added iron through its co-precipitation with hydrated oxide of iron at $\mathrm{pH} 7.0$ and $20 \pm 1^{\circ} \mathrm{C}$ is between 9.3 and $9.5 \mathrm{mg} / \ell$.

Table 3 presents the result on co-precipitation of silica in hypolimnionic water of Lake Kizaki. The difference in the dissolved silica content of hypolimnionic water before and after precipitation of hydrated oxides of iron and manganese is between 
Table 2. Co-precipitation of silica with hydrated oxides of iron and manganese in hypolimnionic water of Lake Aburagafuchi, a eutrophic brackish lake in Aichi Pref., Japan (Oct. 2, 1967; depth 3.0m).

\begin{tabular}{|c|c|c|c|c|c|c|c|c|c|c|}
\hline \multicolumn{8}{|c|}{ Original lake water } & \multicolumn{3}{|c|}{ After precipitation of hydrated oxides } \\
\hline $\begin{array}{c}\text { Depth } \\
\mathrm{m}\end{array}$ & $\mathrm{pH}$ & $\begin{array}{c}\text { Temp. } \\
{ }^{\circ} \mathrm{C}\end{array}$ & $\begin{array}{l}\mathrm{Cl} \\
\mathrm{g} / \mathrm{l}\end{array}$ & $\begin{array}{c}\text { Dissolved } \\
\mathrm{O}_{2} \\
\mathrm{~m} \ell / \mathrm{l}^{2}\end{array}$ & $\begin{array}{c}\text { Dissolved } \\
\mathrm{SiO}_{2} \\
\mathrm{mg} / \ell\end{array}$ & $\begin{array}{c}\text { Total* } \\
\mathrm{Fe}(\mathrm{Fe}++) \\
\mathrm{mg} / \ell\end{array}$ & $\begin{array}{l}\text { Total* } \\
\mathrm{Mn} \\
\mathrm{mg} / \ell\end{array}$ & $\begin{array}{c}\text { Dissolved } \\
\mathrm{SiO}_{2} \\
\mathrm{mg} / \ell\end{array}$ & $\begin{array}{c}\text { Dissolved } * * \\
\mathrm{Fe} \\
\mathrm{mg} / \ell\end{array}$ & $\begin{array}{l}\text { Dissolved** } \\
\mathrm{Mn} \\
\mathrm{mg} / \ell\end{array}$ \\
\hline 2.0 & 7.3 & 20.2 & 9.87 & 0.01 & 18.8 & $15.8(13.5)$ & 1.1 & 14.5 & 0.03 & 0.02 \\
\hline 2.6 & 7.3 & 20.3 & 10.51 & 0.00 & 17.2 & $18.0(16.1)$ & 1.4 & 14.8 & 0.03 & 0.03 \\
\hline 2.9 & 7.1 & 21.2 & 10.74 & 0.00 & 18.0 & $16.5(14.5)$ & 1.7 & 15.9 & 0.04 & 0.03 \\
\hline
\end{tabular}

Table 3. Co-precipitation of silica with hydrated oxides of iron and manganese in hypolimnionic water of Lake Kizaki, a mesotrophic mountain lake in Nagano Pref., Japan (Oct. 30-31, 1966; depth 28.3 m).

\begin{tabular}{|c|c|c|c|c|c|c|c|c|c|c|}
\hline \multicolumn{8}{|c|}{ Original lake water } & \multicolumn{3}{|c|}{ After precipitation of hydrated oxides } \\
\hline $\begin{array}{c}\text { Depth } \\
\mathrm{m}\end{array}$ & $\mathrm{pH}$ & $\begin{array}{l}\text { Temp. } \\
{ }^{\circ} \mathrm{C}\end{array}$ & $\begin{array}{c}\mathrm{Cl} \\
\mathrm{mg} / \mathrm{l}\end{array}$ & $\begin{array}{c}\text { Dissolved* } \\
\mathrm{O}_{2} \\
\mathrm{~m} \ell / \ell\end{array}$ & $\begin{array}{c}\text { Dissolved } \\
\mathrm{SiO}_{2} \\
\mathrm{mg} / \hat{\ell}\end{array}$ & $\begin{array}{c}\text { Dissolved } \\
\mathrm{Fe}(\mathrm{Fe}++*) \\
\mathrm{mg} / \ell\end{array}$ & $\begin{array}{c}\text { Dissolved } \\
\mathrm{Mn} \\
\mathrm{mg} / \ell\end{array}$ & $\begin{array}{c}\text { Dissolved } \\
\mathrm{SiO}_{2} \\
\mathrm{mg} / \ell\end{array}$ & $\begin{array}{c}\text { Dissolved } \\
\mathrm{Fe} \\
\mathrm{mg} / \ell\end{array}$ & $\begin{array}{c}\text { Dissolved } \\
\mathrm{Mn} \\
\mathrm{mg} / \ell\end{array}$ \\
\hline 25.0 & 6.4 & 6.5 & 1.2 & 0.00 & 12.0 & $0.9(0.32)$ & 1.0 & 11.9 & 0.03 & 0.03 \\
\hline 27.5 & 6.4 & 6.4 & 1.0 & 0.00 & 13.0 & $3.9(3.68)$ & 3.2 & 12.6 & 0.04 & 0.03 \\
\hline 28.0 & 6.5 & 6.4 & 1.3 & 0.00 & 13.0 & $4.1(3.68)$ & 4.1 & 12.6 & 0.04 & 0.03 \\
\hline 28.25 & 6.6 & - & 1.3 & 0.00 & 13.4 & $5.2(4.80)$ & 3.9 & 13.1 & 0.04 & 0.04 \\
\hline
\end{tabular}

* Determined by KoYAMA and TOMINo (1967).

0.1 and $0.4 \mathrm{mg} / \ell$. The difference for artificial solutions containing 12.0 and $13.0 \mathrm{mg} / \ell$ of dissolved silica, and 0.9 and $3.8 \mathrm{mg} / \ell$ of added iron at $\mathrm{pH} 6.5$ and $20 \pm 1^{\circ} \mathrm{C}$ is 0.4 and $1.1 \mathrm{mg} / \ell$, respectively. The hydrated oxides hardly co-precipitate dissolved silica in this lake water.

The efficiency of co-precipitation of silica with hydrated oxides of iron and manganese is greatly reduced in lake water as compared with that in the silica solution prepared in the laboratory. The decrease in the efficiency of co-precipitation is hardly due to inorganic materials and mainly due to organic materials in natural lake water (KATo, 1969, data unpublished.).

To examine the effect of these materials on the efficiency of co-precipitation of silica with the hydrated oxides, a known amount of dissolved iron or manganese in acid solution was added to waters of Lake Aburagafuchi and Lake Kizaki. The results are given in Table 4. The weight ratio of precipitated iron to co-precipitated silica 
Table 4. Co-precipitation of silica with hydrated oxides of iron and manganese after adding iron or manganese in acid solution to hypolimnionic waters of Lake Aburagafuchi (Oct. 2, 1967) and Lake Kizaki (Oct. 30-31, 1966)

\begin{tabular}{|c|c|c|c|c|c|c|c|c|c|c|}
\hline & \multicolumn{5}{|c|}{ Original lake water } & \multicolumn{5}{|c|}{ After precipitation of hydrated oxides } \\
\hline & \multirow{3}{*}{$\begin{array}{c}\text { Depth } \\
\text { m }\end{array}$} & \multirow{3}{*}{$\mathrm{pH}$} & \multirow[b]{3}{*}{$\begin{array}{l}\text { Dis. } \\
\mathrm{SiO}_{2} \\
\mathrm{mg} / \ell\end{array}$} & \multirow[b]{3}{*}{$\begin{array}{l}\text { Dis. } \\
\mathrm{Fe} \\
\mathrm{mg} / \mathrm{l}\end{array}$} & \multirow[b]{3}{*}{$\begin{array}{l}\text { Dis. } \\
\mathrm{Mn} \\
\mathrm{mg} / \ell\end{array}$} & \multirow{2}{*}{\multicolumn{2}{|c|}{$\begin{array}{l}\text { Without addition } \\
\text { of metal } \\
\text { Co-ppted }\end{array}$}} & \multicolumn{3}{|c|}{ After addition of } \\
\hline & & & & & & & & $\mathrm{Fe} 11$ & $\mathrm{mg} / \ell$ & Mn $10.0 \mathrm{mg} / \mathrm{l}$ \\
\hline & & & & & & $\begin{array}{c}\text { Co-ppted } \\
\mathrm{SiO}_{2} \\
\mathrm{mg} / \ell\end{array}$ & $\mathrm{Fe} / \mathrm{SiO}_{2}$ & $\begin{array}{c}\text { Co-ppted } \\
\mathrm{SiO}_{2} \\
\mathrm{mg} / \ell\end{array}$ & $\mathrm{Fe} / \mathrm{SiO}_{2}$ & $\begin{array}{c}\text { Co-ppted } \\
\mathrm{SiO}_{2} \\
\mathrm{mg} / \ell\end{array}$ \\
\hline \multirow{3}{*}{$\begin{array}{c}\text { Lake } \\
\text { Aburagafuchi }\end{array}$} & 2.0 & 7.3 & 18.8 & 15.8 & 1.1 & 3.4 & 4.6 & 8.1 & 3.4 & 5.7 \\
\hline & 2.6 & 7.3 & 17.2 & 18.0 & 1.4 & 2.4 & 7.5 & 6.9 & 4.3 & 3.7 \\
\hline & 2.9 & 7.1 & 18.0 & 16.5 & 1.7 & 2.1 & 7.9 & 6.1 & 4.6 & 3.3 \\
\hline \multirow{4}{*}{$\begin{array}{l}\text { Lake } \\
\text { Kizaki }\end{array}$} & 25.0 & 6.4 & 12.0 & 0.9 & 1.0 & 0.1 & 9.0 & 3.2 & 3.8 & \\
\hline & 27.5 & 6.4 & 13.0 & 3.9 & 3.2 & 0.4 & 9.8 & 3.8 & 4.0 & \\
\hline & 28.0 & 6.5 & 13.0 & 4.1 & 4.1 & 0.4 & 10.3 & 3.7 & 4.2 & \\
\hline & 28.25 & 6.6 & 13.4 & 5.2 & 3.9 & 0.3 & 17.3 & 3.3 & 5.0 & \\
\hline
\end{tabular}

$\mathrm{Fe} / \mathrm{SiO}_{2}$ is weight ratio of precipitated iron to co-precipitated silica.

is smaller in the case of adding iron than without adding iron. This means that the efficiency of co-precipitation of silica is larger in the former than in the latter. The larger amounts of added iron and manganese give less effect of some materials on the efficiency of co-precipitation of silica with the hydrated oxides.

Therefore the amount of co-precipitated silica at given temperature and $\mathrm{pH}$ value depends on the amounts of iron, manganese and some materials which reduce the efficiency of co-precipitation.

Existence and disappearance of hydrated oxides of iron and manganese including co-precipitated silica at the surface of bottom sediment of lake

Existence of hydrated oxides of iron and manganese with co-precipitated silica at the surface of bottom sediment of lake under aerobic condition and their disappearance under anaerobic condition support the significance of co-precipitation of silica with the hydrated oxides and dissolution of co-precipitated silica in controlling dissolved silica in lake water.

Orange floccules of hydrated oxides of iron and manganese are sampled from the bottom sediment of Lake Kizaki under aerobic condition of its water (January to June). Table 5 gives the results on dissolution of orange floccules sampled on April 16, 1968. One hour after adding $1 \mathrm{M}$ perchloric acid to distilled water containing orange floccules, the dissolved silica content as well as the dissolved iron and manganese contents of the solution increases. The silica content of orange floccules is about a sixth of their iron plus manganese content. On the other hand, the results 
Table 5. Dissolution of orange floccules of hydrated oxides of iron and manganese sampled from the bottom sediment at the circulation period of Lake Kizaki (April 26, 1968)

\begin{tabular}{cccc|ccc}
\hline & \multicolumn{3}{c|}{$\begin{array}{c}\text { Distilled water containing } \\
\text { orange floccules }\end{array}$} & \multicolumn{3}{c}{$\begin{array}{c}\text { After the addition of } \\
\text { perchloric acid }\end{array}$} \\
\hline $\begin{array}{c}\text { Run } \\
\text { No. }\end{array}$ & $\begin{array}{c}\text { Dissolved } \\
\mathrm{SiO}_{2} \\
\mathrm{mg} / \ell\end{array}$ & $\begin{array}{c}\text { Dissolved } \\
\mathrm{Fe} \\
\mathrm{mg} / \ell\end{array}$ & $\begin{array}{c}\text { Dissolved } \\
\mathrm{Mn} \\
\mathrm{mg} / \ell\end{array}$ & $\begin{array}{c}\text { Dissolved } \\
\mathrm{SiO}_{2} \\
\mathrm{mg} / \ell\end{array}$ & $\begin{array}{c}\text { Dissolved } \\
\mathrm{Fe} \\
\mathrm{mg} / \ell\end{array}$ & $\begin{array}{c}\text { Dissolved } \\
\mathrm{Mn} \\
\mathrm{mg} / \ell\end{array}$ \\
\hline 1 & 0.1 & $<0.1$ & $<0.1$ & 34.0 & 108 & 83.5 \\
2 & 0.1 & $<0.1$ & $<0.1$ & 32.5 & 101 & 85.0 \\
3 & 0.2 & $<0.1$ & $<0.1$ & 45.5 & 228 & 132 \\
4 & 0.1 & $<0.1$ & $<0.1$ & 18.0 & 54.0 & 40.5 \\
5 & 0.1 & $<0.1$ & $<0.1$ & 19.5 & 59.0 & 35.5 \\
\hline
\end{tabular}

on co-precipitation of silica with the hydrated oxides in hypolimnionic water of Lake Kizaki presented in Table 3 show that the silica content of the hydrated oxides is only about a twentieth of their iron plus manganese content. This is inconsistent with the results presented in Table 5 . The inconsistency still remains unsolved.

No orange floccule can be observed at the surface of bottom sediment of Lake Kizaki at the latter half of stagnation period (September to November). Disappearance of orange floccules is obviously attributed to dissolution of hydrated oxides of iron and manganese in the hypolimnion. The results given in Table 5 confirm that disappearance of orange floccules causes a simultaneous increase in the dissolved silica content with increase in the dissolved iron and manganese contents of hypolimnionic water.

\section{CONCLUSION}

Dissolved silica is removed from solutions through its co-precipitation with hydrated oxides of iron and manganese. Dissolution of silica co-precipitated with the hydrated oxides causes a simultaneous increase in the dissolved silica content with an increase in the dissolved iron and manganese contents of solutions under anaerobic condition. The significance of co-precipitation of silica with the hydrated oxides and dissolution of co-precipitated silica for the behavior of dissolved silica in lake water is supported by existence of hydrated oxides of iron and manganese (orange floccules) including co-precipitated silica at the surface of bottom sediment under aerobic condition and their disappearance under anaerobic condition.

Through these phenomena the behavior of dissolved silica is controlled by the oxidation-reduction cycle in lake water. So, it becomes reasonable that the seasonal variation of the vertical distribution pattern of dissolved silica resembles that of not only iron and manganese but also phosphorus, iodine and arsenic, the behavior of 
which is attributed to the oxidation-reduction of iron and manganese.

The efficiency of co-precipitation of silica with the hydrated oxides is reduced in natural lake water as compared with that in the silica solution prepared in the laboratory experiment. The amount of dissolved silica co-precipitated with the hydrated oxides depends on the amounts of iron, manganese and some materials reducing the efficiency of co-precipitation of silica in lake water.

\section{ACKNOWLEDGMENTS}

I am greatly indebted to Prof. Y. KITANO, Water Research Laboratory, Nagoya University, for his valuable advice and encouragement. I wish to express my thanks to Prof. T. KoYAMA, Dr. N. HANDA and their co-workers, and also to Dr. S. KANAMORI and Mr. T. OMORI, Water Research Laboratory, for their discussions and collection of samples.

\section{REFERENCES}

EINSELE, W. (1936) Über die Beziehungen des Eisenkreislaufs zum Phosphatkreislauf im eutrophen See. Arch. f. Hydrobiol. 29, 664-686.

EINSELE, W. (1938) Über chemische und kolloidchemische Vorgänge in Eisen-phosphat-systemen unter limnochemischen und limnogeologischen Gesichtspunkten. ibid. 33, 361-387.

ELSTER, H. J. (1939) Beobachtungen über das Verhalten der Schichtgrenzen nebst einigen Bemerkungen über die Austauschverhältnisse im Bodensee (Obersee). ibid. 35, 286-346.

HARDER, H. (1965) Experimente zur "Ausfällung" der Kieselsäure. Geochim. Cosmochim. Acta 29, 429-442.

HARRIS, R. C. (1967) Silica and chloride in interstitial waters of river and lake sediments. Limnol. Oceanogr. 12, 8-12.

IWASAKI, I., UTSUMI, S., HAGINO, K. and OZAWA, T. (1956) A new spectrophotometric determination of small amounts of chloride using the mercuric thiocyanate method. Bull. Chem. Soc. Japan $29,860-864$.

KANAMORI, S. (1965) Geochemical study of arsenic in natural waters. III. The significance of ferric hydroxide precipitate in stratification and sedimentation of arsenic in lake water. $\mathbf{J}$. Earth Sci. Nagoya Univ. 13, 46-57.

KATO, K. and KitANO, Y. (1966) Salt error in colorimetric determination of the molybdatereactive silica in sea water. ibid. 14, 151-158.

Koyama, T. and Sugawara, K. (1951) Sulphate co-precipitation in lake and sea and its concentration in the bottom deposits. J. Oceanogr. Soc. Japan 6, 190-193.

Koyama, T. and Tomino, T. (1967) Decomposition process of organic carbon and nitrogen in lake water. Geochem. J. 1, 109-124.

LEWIN, J. C. (1954) Silicon metabolism in diatom. I. Evidence for the role of reduced sulfur compounds in silicon utilization. J. Gen. Physioi. 37, 589-599.

LEwIN, J. C. (1955) Silicon metabolism in diatom. III. Respiration and silicon uptake in Navicula pelliculosa. ibid. 39, 1-10.

Meloche, V. M., Leader, G., Safranski, L. and Juday, C. (1938) The silica and diatom content of Lake Mendota water. Trans. Wis. Acad. Sci. Arts Lett. 31, 363-376. 
MORTIMER, C. H. $(1941,1942)$ The exchange of dissolved substances between mud and water in lakes. J. Ecol. 29, 280-329, 30, 147-201.

Moss, M. L. and MELLON, M. G. (1942) Colorimetric determination of Fe with 2, 2'-bipyridyl and 2, 2', 2'-terpyridyl. Ind. Eng. Chem., Anal. Ed. 14, 862-865.

OHLE, W. (1953) Phosphor als Initialfaktor der Gewässereutrophierung. Vom Wasser 20, 11-23.

Sugawara, K., KoYAma, T. and TERADA, K. (1958) Co-precipitation of iodide ions by some metallic hydrated oxides with special reference to iodine accumulation in bottom water layers and in interstitial water of muds in some Japanese lakes. J. Earth Sci. Nagoya Univ. 6, $52-61$.

Vinogradov, A. P. and Boichenko, E. A. (1942) Decomposition of kaolin by diatoms. C. R. Acad. Sci. U. S. S. R. 37, 135-138.

YoshimuRA, S. (1930) Seasonal variation of silica in Takasuka-numa, Saitama. Jap. J. Geol. Geogr. 7, 101-113.

YoSHIMURA, S. (1931) Seasonal variation of iron and manganese in the water of Takasuka-numa, Saitama. ibid. 8, 269-279.

YOSHIMURA, S. (1939) Seasonal variation of silica- and diatom-contents of the water of Takasukapond, Saitama, Japan. Jubilee publication in the commemoration of Prof. H. YABE, M. I. A. sixtieth birthday, Vol.1, pp. 261-282. 